\title{
The Application of Fuzzy Logic Control Systems on Harvesting Standard Operating Procedures Models of Sesame Crops in Indonesia
}

\author{
Luluk Sulistiyo Budi $^{\#}$ and Ratna Mustika Wardhani ${ }^{\#}$ \\ ${ }^{\#}$ Faculty of Agriculture, Agrotechnology Studies Program,Merdeka Madiun University,East Java, Indonesia \\ E-mail: luluksb@unmer-madiun.ac.id; ratnamustika@unmer-madiun.ac.id
}

\begin{abstract}
The development of modern technologies of cultivation must continue, although the conventional harvesting technologies are still providing benefits. For that purpose, we need a comprehensive, effective and efficient standard operating procedures (SOP). This research applies the fuzzy logic control system to construct Standard Operating Procedures (SOP) models of technology models for the harvesting of sesame cultivation. The research method used were literature studies, field research and expert discussion in Madiun, the center of sesame plantation in Indonesia. Standard operating procedure components and criteria including models for harvesting technology, drying technology and separating of seeds. The results are standard operating procedures consisting of models for the harvesting of sesame crop, drying and separating of seeds effectively and efficiently. The package system of SOP for decisionmaking, the holistic rule-base was considered which consist of the plant, labor, location and available technology. The example of Rule-Base 'If Then', if varieties branched or not, the Single row or Double row, the location drying is limited, labor is limited, and the technology is available, the goal model harvest without No Tied, as decisions and so on for rule-rule others, and it has been available in Software.
\end{abstract}

Keywords — design; harvesting models; standard operating procedures; rule-base; Sesamum indicum L.

\section{INTRODUCTION}

Sesame plant (Sesamum indicum L.) is an annual plant which is potential fro dry land [1]. In Ethiopia, this plant is the first ranking for the year 2013 for the production of oil from seeds [2]. In Indonesia, the sesame plant growth is considered suitable for micro-climate. The fact is that there are not many areas in Indonesia can be developed for the center of crop plantation. This led to the lower domestic production capacity of sesame. This has an impact on government policy on determining the import option for this commodity [3]. In fact, the sesame seed is an important factor, in this case, the raw material to develop local materials based on sesame agro-industry potential in Indonesia (4). However, the oil content of sesame seed is different from each other [5].

There are many types of sesame seeds based on the color namely black sesame, white sesame, and brown sesame seeds. Based on the appearance of plants, there are plants without branches, branch with many vertical direction and branch that spread much. Besides, based on the form of pods, there are four spaces, six spaces, and eight spaces. Based on the shape of rooting, sesame is divided into two kinds of roots namely deep and shallow roots; it is closely related to the form of branching and the age of the plant as well as resistance to drought [6].

Differences in the appearance of sesame plants are vital to getting the attention of the decision to increase the production of crops. Decision-making, especially harvesting standard operating procedures of sesame plants is needed to be developed. Standard operating procedures for harvesting systems include harvesting technology, drying technology, and the separating of sesame seeds [7-8]. Harvesting technology includes cutting without bound, cut into small bundles, and long cut ties [9-10]. Drying techniques include horizontal drying, and drying cone-shaped or inverted $\mathrm{V}$ triangle. Seed separation technology includes Tampi hit, hit the blower, the blower and milling [11]. Various methods of harvesting will result if the plants are harvested at the right age at maturity is $90 \%$ (percent) [12]. The purpose of this study was to obtain the comprehensive, effective and efficient standard operating procedures of the harvesting of sesame plant (Sesamum indicum L.).

One way to get the standard operating procedure is to predict the determinants by problem-solving methodology using the application of fuzzy logic control systems. This system is suitable to be implemented in the system based on data acquisition and control system [13]. 
The final result of the standard operating procedure is the best decision which is taken from various opportunities with the help of "rule-based if and then". The consultation base which is used in the methodology is sesame crop models. The objective of this research is to construct a comprehensive, effective and efficient standard operating procedure (SOP) models for the harvesting of sesame cultivation by application of fuzzy logic control system.

\section{MATERIAL AND METHOD}

\section{A. Material and Place}

Fieldwork on dry land of Sugihwaras village districts Saradan Madiun, East Java Indonesia which the altitude of $65 \mathrm{~m}$ above sea level and in the paddy field of Banjarejo Village, District Taman Madiun which the altitude of $63 \mathrm{~m}$ above sea level.from March to August 2015. The materials used in this research including six types of seed varieties of SBR1, SBR2, SBR3, SBR4, H2 and M2, organic fertilizers, chemical fertilizers, and pesticides.

\section{B. Method}

The method used is the application of Mamdani fuzzy logic on field research result, and depth interviewed with experts to obtain primary and secondary data from the literature review about models for harvesting, drying and separation models seeds. The possibility of fuzzy logic membership value is between 0 and 1 that could be stated as two values "Yes and No," "Right and Wrong," "Good and Bad", "Small and Large", "Wide and Narrow" simultaneously. However high its value depends on the weight of membership. The application of fuzzy logic required fuzzy variables, fuzzy set, the discourse and the domain of fuzzy sets [14].

The Mamdani Fuzzy logic includes the fuzzification and the establishment of a knowledge base of fuzzy (rule-base in the form of IF ... THEN), application functionality implications of using the MIN function and composition of the inter-rule using the function MAX (produce fuzzy set new), and defuzzification using Centroid, through the components of the model. The next stage is to draw up the standard operating procedures holistically, make decisions based on data, knowledge, and models that produced Database, Knowledge-base and arranged in a Model-base management system to create a consultation [15]-[16].

\section{Research Stage}

The research was initiated by the selection of experts which consist of practitioners, academics, and public officials from the department of agriculture. Each expert conducts an inventory and verifies the criteria and indicators as the key elements stages of yield component of primary and secondary data includes sub-models of harvesting, drying, and sub-sub-division. Each element generates fuzzy membership function set as low, medium, and high. It is continued by the establishment of the fuzzy knowledge base (rule-base in the form of if ... then, sub-SOP harvest, subSop Drying, and Sub-SOP separation. The next stage of the preparation of SOP Harvest Sesame and verified, if correct, it will be continued with the validation which results in the SOP Models of sesame harvesting models.

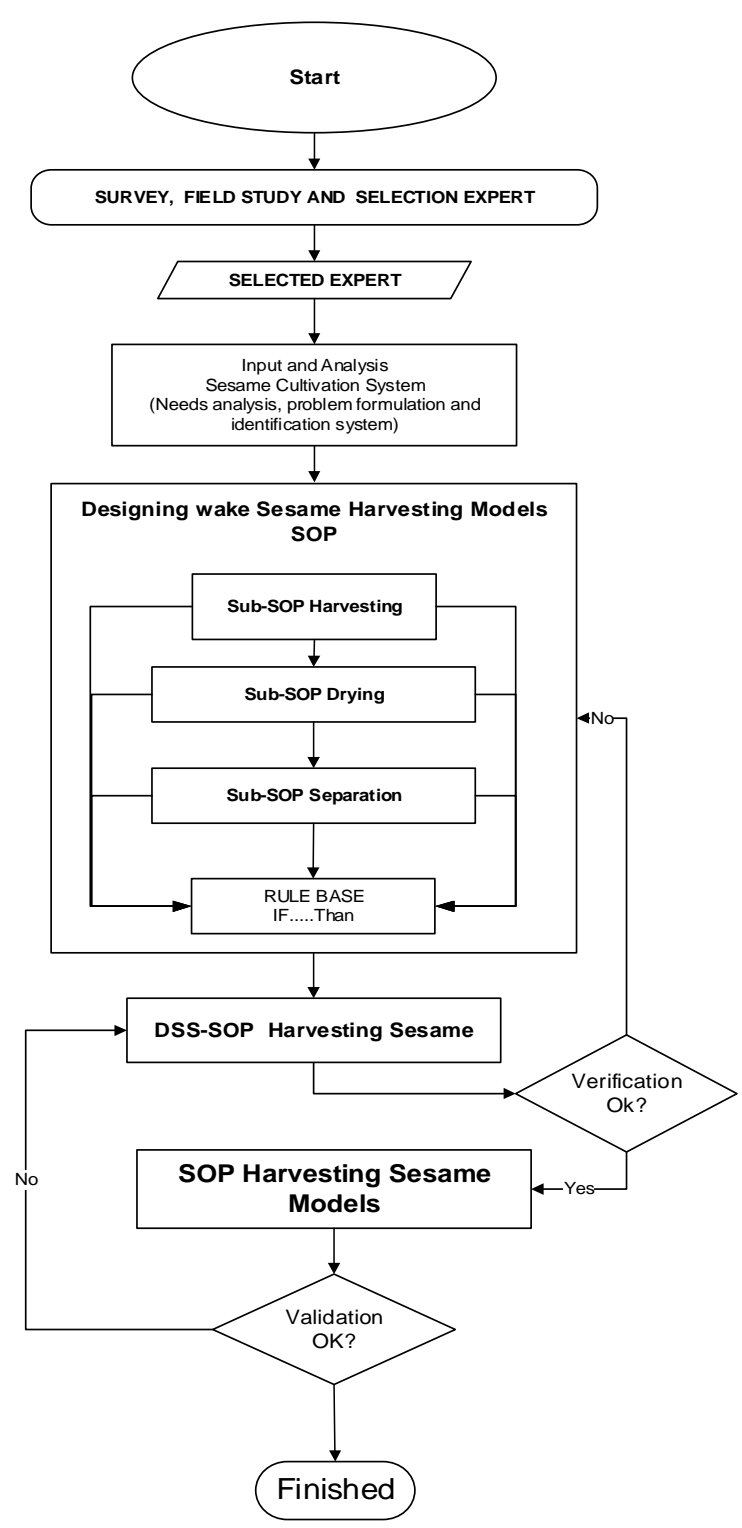

Fig. 1 Flow chart stages of research

\section{Analysis}

The analysis uses fuzzy inference system, where each the criteria and the indicators do formation fuzzy set membership and subsequently form a knowledge base ifthen based on expert opinion to determine the goals and alternatives or decisions that can make it easier to determine the sesame crop harvesting activities on the circumstances that exist on the user [17].

\section{RESULTS AND DISCUSSION}

The results of expert discussion in the decision making of harvesting technology in sesame crop cultivation were 8 factors and 1 goal. Based on fuzzy logic, the fuzzy sets were arranged of the factors that make up the membership of the appropriate weighting of criteria, called indicators. Factors that could be possible to be the determinant of crop varieties technology selection, planting models, acreage, drying, 
where the drying area, the availability of personnel, the availability of technology and seed separation technique.

Sesame is one of the gentlest crops on harvesting equipment, so technology setting that will work in all conditions are needed [6]. Analysis of the harvesting technology which includes the drying and separation of the seeds shows a broad range of scenarios, each of which has been arranged into sub-models for harvesting technology, sub-models for drying technology and sub-models for the separation of grains. There are several criteria and indicator as a result of the expert verification (Table 1).

TABLE I

THE RESULTS OF THE EXPERT VERIFICATION OF THE CRITERIA AND INDICATORS OF FACTORS HARVESTING TECHNOLOGY

\begin{tabular}{|c|c|}
\hline Criteria & Indicator \\
\hline \multirow[t]{3}{*}{ 1. Harvest technology } & No Tied/bundles \\
\hline & Small tied/bundles \\
\hline & Large tied/bundles \\
\hline \multirow[t]{3}{*}{ 2. Drying } & inverted V \\
\hline & Cone type/bundles \\
\hline & horizontal type \\
\hline \multirow[t]{3}{*}{ 3. Plant of Models } & Single row \\
\hline & Double Row \\
\hline & Square \\
\hline \multirow[t]{4}{*}{ 4. Planting Area } & Narrow \\
\hline & Moderate \\
\hline & Wide \\
\hline & Very Wide \\
\hline \multirow[t]{2}{*}{ 5.Varieties of sesame } & Branch \\
\hline & No branch \\
\hline \multirow{3}{*}{ 6. Available Labor } & Limited $(<5$ people $/ \mathrm{Ha})$ \\
\hline & $\begin{array}{l}\text { Moderate (6-10 people } \\
/ \mathrm{Ha})\end{array}$ \\
\hline & Many (> 10 people $/ \mathrm{Ha}$ \\
\hline \multirow{3}{*}{ 7. Location drying } & Limited $(<5 \%)$ \\
\hline & Moderate (6-10\%) \\
\hline & Broad (>10\%) \\
\hline \multirow{3}{*}{ 8.Available Technology } & Limited / conventional \\
\hline & Moderate /semi-modern \\
\hline & Available/Modern \\
\hline \multirow{3}{*}{ 9.Separation } & Behind and beaten \\
\hline & Winnowing tray \\
\hline & Dozer and blower \\
\hline
\end{tabular}

There are nine (9) criteria, and each criterion has several indicators (Table 1). Preparation of sub-models of the harvest can be carried out with regard to varieties, planting method, labor, location, and availability of tools. The Submodels for the harvesting of sesame can be seen in Fig. 2 .

Unbranched varieties are suitable to develop in doublerow planting model in a wide field and the technology available, but workers are limited. It is efficient to harvest in smaller bundles. In contrary, for branched varieties is suitable to develop in a single row or squared planting model.

Availability of labor will greatly affect the effectiveness of crop harvesting and determine the model, where the model without bundles/tied harvest will increase the productivity of the workers compared with a model in large bundles or small bundles/tied [6]. The average value of observed labor productivity on harvesting influence the planting models and varieties planted are presented in Table 2.

The results of in-field research on the level of energy efficiency showed a real difference. Where the technique of harvest without not tied shows high efficient reach $30 \%$, then in large tied $19,32 \%$ and in small tied only $0,05 \%$. The complete observations are presented in Fig. 2.

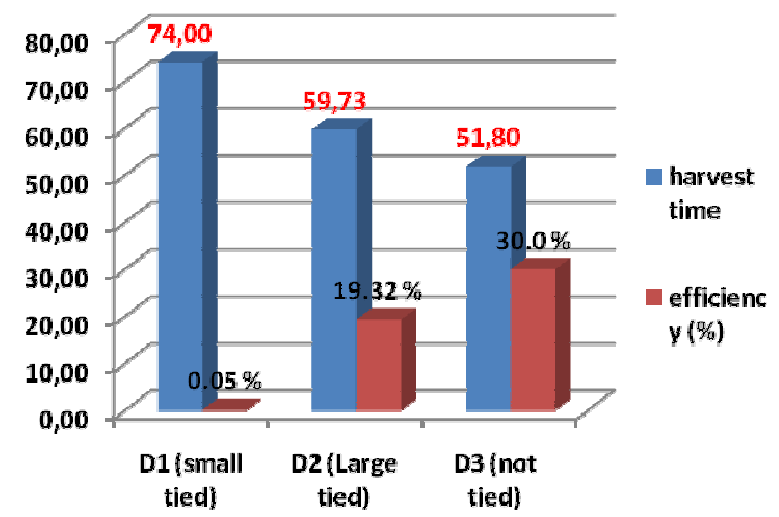

Fig. 2 Power efficiency level of harvest model (m2)

TABLE II

The Average Value of the ObSERVATION of LABOR PROdUCTIVITy PeR UNIT AREA OF CROP PLANTING

\begin{tabular}{|c|c|c|c|c|}
\hline No & $\begin{array}{c}\text { Harvesting } \\
\text { Model }\end{array}$ & $\begin{array}{c}\text { Planting } \\
\text { Models }\end{array}$ & $\begin{array}{c}\text { Varieties } \\
\text { of sesame }\end{array}$ & $\begin{array}{c}\text { Average } \\
\text { productivity } \\
\left(\mathbf{m}^{\mathbf{2}} \mathbf{)} \text { person/ }\right. \\
\text { day }\end{array}$ \\
\hline 1 & Small tied & Single row & & 400 \\
\hline 2 & Small tied & Double row & & 350 \\
\hline 3 & Small tied & Square & & 420 \\
\hline 4 & Small tied & & Branch & 420 \\
\hline 5 & Small tied & & No branch & 380 \\
\hline 6 & Large tied & Single row & & 550 \\
\hline 7 & Large tied & Double row & & 500 \\
\hline 8 & Large tied & Square & & 570 \\
\hline 9 & Large tied & & Branch & 550 \\
\hline 10 & Large tied & & No branch & 500 \\
\hline 11 & Not Tied & Single row & & 700 \\
\hline 12 & No Tied & Double row & & 700 \\
\hline 13 & No Tied & Square & & 750 \\
\hline 14 & No Tied & & Branch & 700 \\
\hline 15 & No Tied & & No branch & 650 \\
\hline
\end{tabular}

There is a varied labor productivity, where the crop models, models of planting and use of improved varieties give an average value of different productivity (Table 2), while the harvesting speed of the results is shown in Fig. 3 


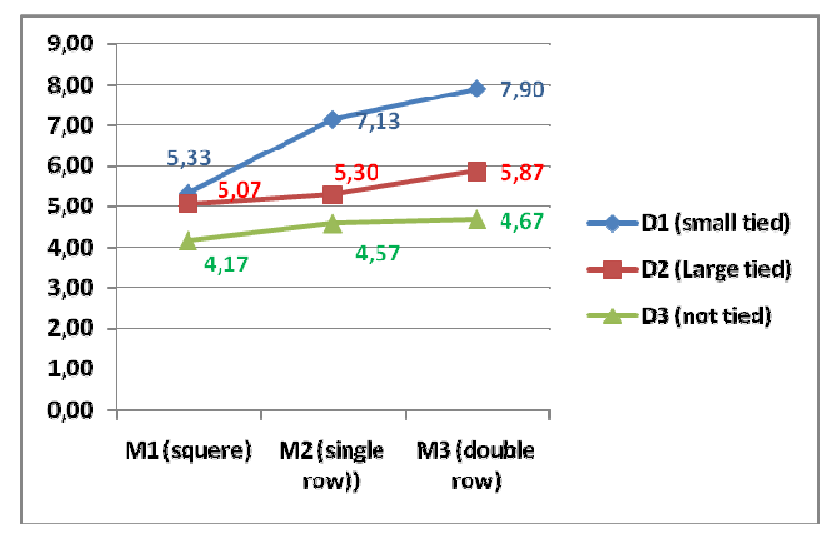

Fig. 3 The speed of harvesting against the cropping model

It can be seen in Fig. 3 that the squere cropping and harvesting models are not tied in the fastest time in the harvest. Appropriate decision making must take into account the value of membership based on field research results for getting the getting the right decision [4].

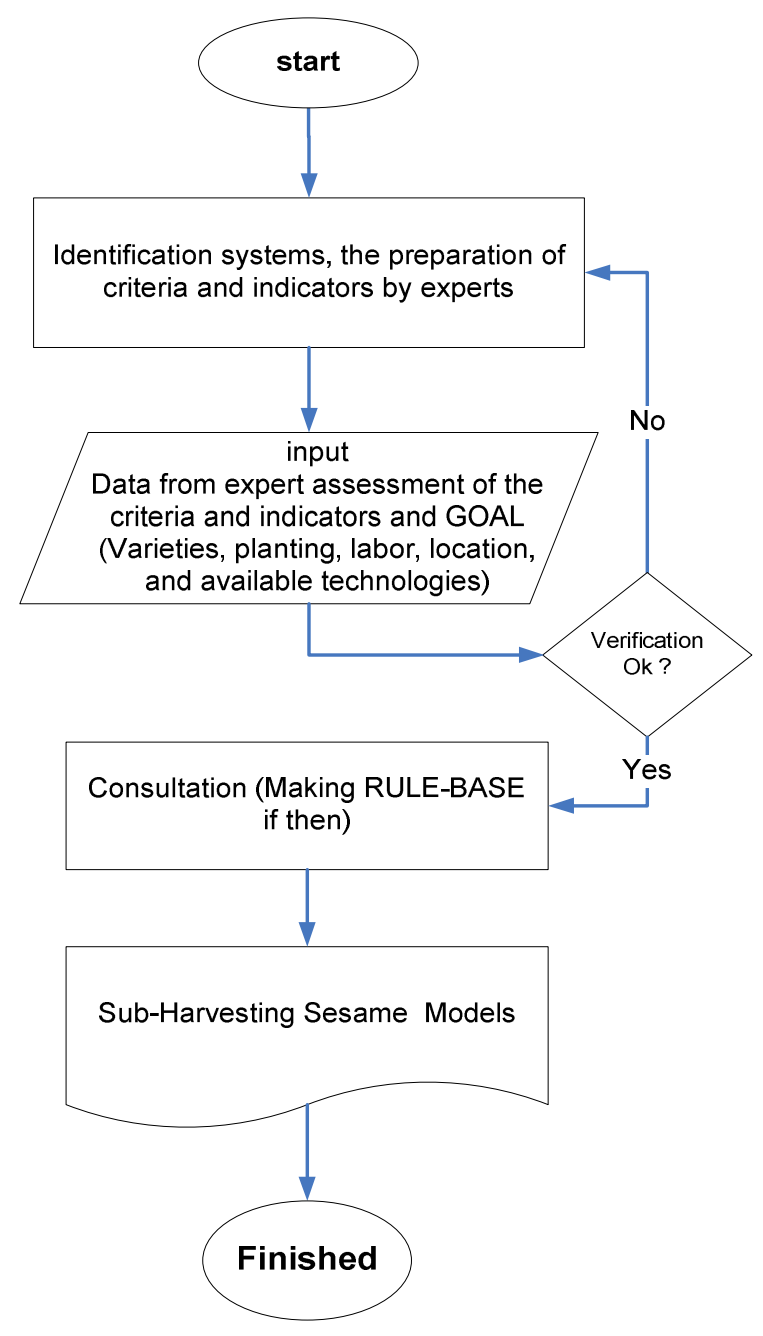

Fig. 4 Sub-model of sesame harvesting

Rule Base sub-models of crop varieties are criteria, a pilot plant, labor, location, drying and equipment available, with a total of 15 indicators of the obtained rule-base of 216 opportunities.

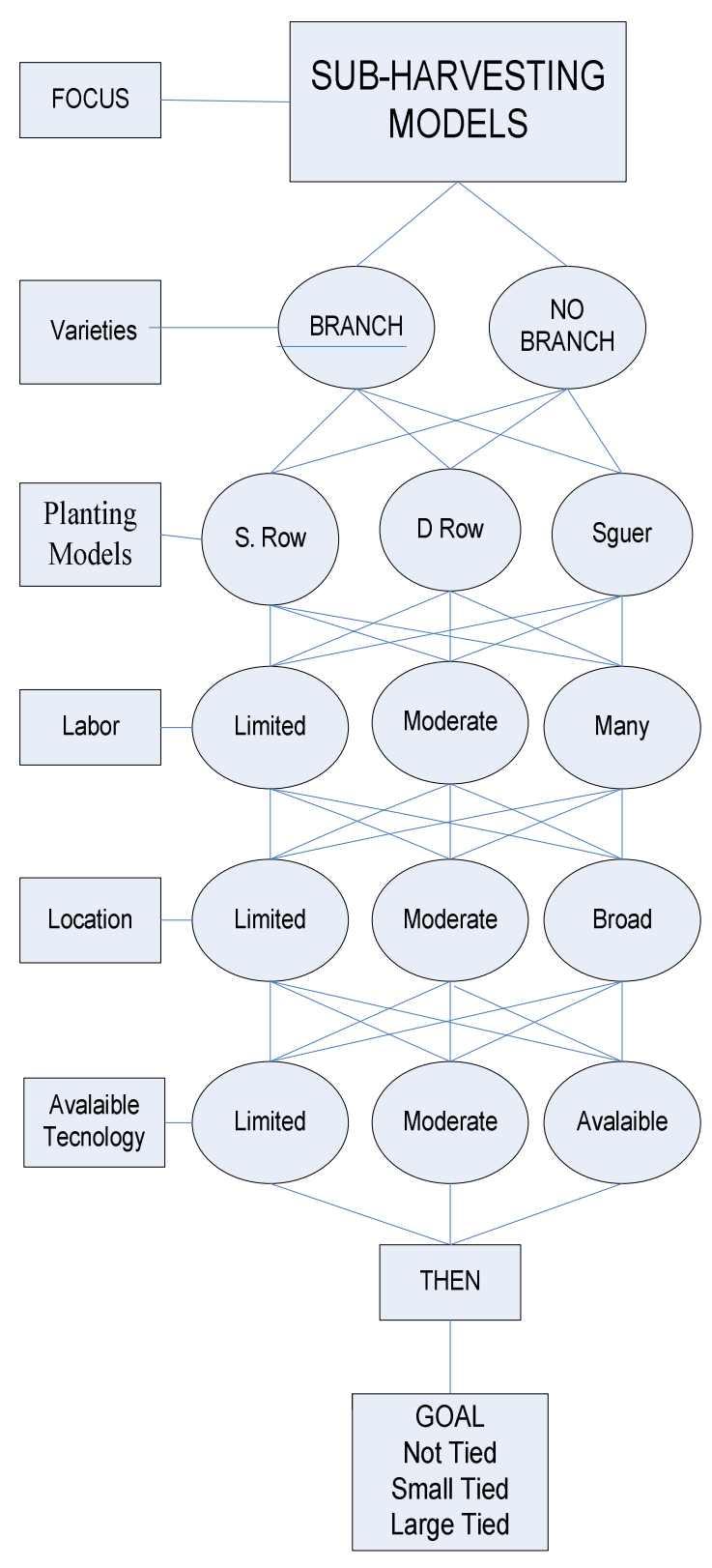

Fig. 5 Structure sub-harvest model

Fig. 5 shows that the sun harvesting models have five criteria that must be considered, where some rules base are arranged in consultation by selecting existing indicators and will get the possibility of a decision of the three alternative crops namely no bundles/ tied, bundles/tied, small and large bundles/tied. However, it is possible to consider related to plant spacing, because the spacing will produce a high seed production or the highest seed yield is gained at $30 \times 10 \mathrm{~cm}$ or $45 \times 10 \mathrm{~cm}$ spacing [18]. Struktur sub- harvest models consist of 5 factors which have various indicators between 2-3. It needs to be arranged of rule-base known as the construction of fuzzy-based knowledge. There is the probability of 486 rule-base. It means that the use of SOP will possibly use one or more decisions in identifying the real condition in the field [14]. 
Harvest sub- structure known models are 5 factors that influence, and each has a variety of indicators that are between $2-3$, then the rule-base preparation is called the establishment of the knowledge base contained 486 fuzzy rule-base, meaning that it allows the user SOP to use one or more decisions after identification of the real conditions on the ground that it faces [14].

The results of the field experiment on the model of drying showed that the drying with cone model gave higher capacity than the others, where the plants were arranged on the tangent end or the cone. Capacity or space occupied a maximum of $70 \%$ with different harvest models. The observations contained in Fig. 6. model more efficient cone in place.

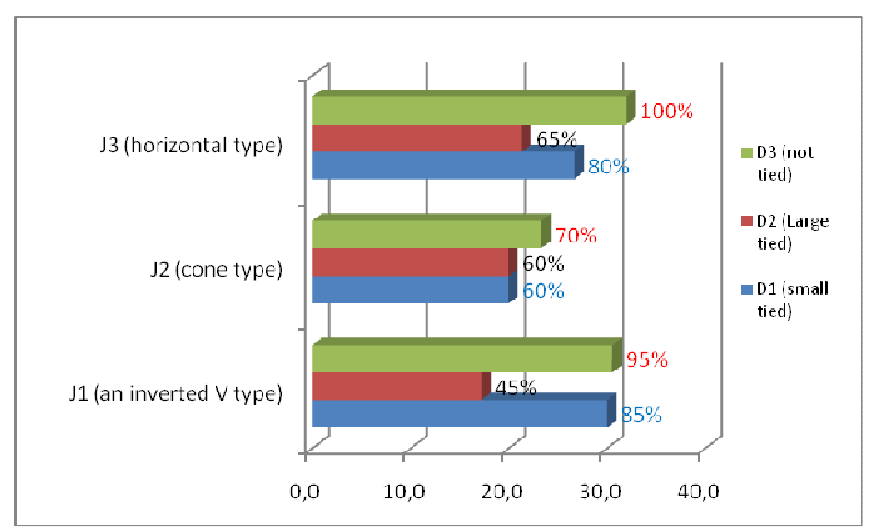

Fig. 6 Capacity to the drying model

Shown in Fig. 6 shows the effect on the loading capacity of the cone type model with large tied, while the rate of dry speed is in Fig. 7.

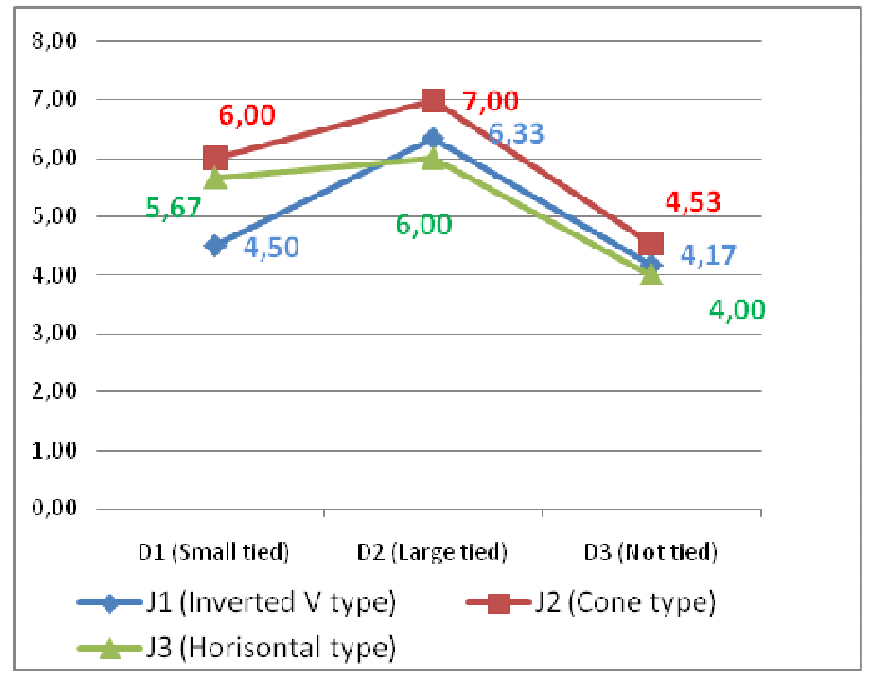

Fig. 7 Dry speed of drying model (day)

Furthermore, the results of the analysis for sub drying models produced sub-models taking into sub-models harvest, labor, location, and availability. Decision making drying more sub-models presented in Fig. 8.

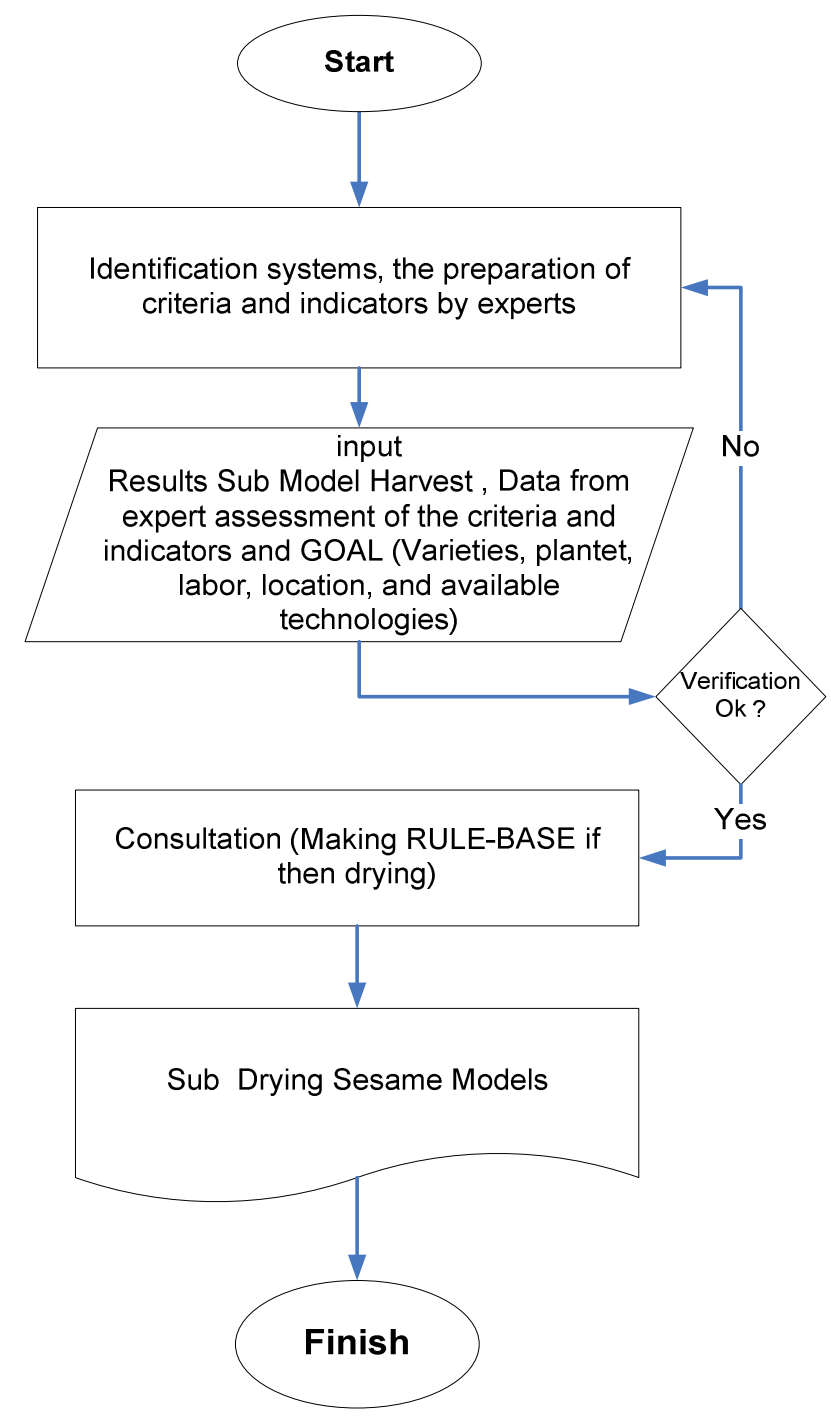

Fig. 8 Flow chart sub-drying models

The complete results of the structural analysis model of the drying sub-models are affected by the results of the harvest, labor, location, and availability of technology. Structures of a sub-rule base model of drying can be seen in Fig. 9.

Fig. 9 shows that sub-models of drying the sesame have five criteria which must consider namely harvesting model, workers, location, and availability of equipment and technology where some rules base are arranged in consultation by selecting the existing indicators and will get the possibility of a decision of the three alternative methods of drying namely inverted V, Cone, and Horizontal type. The correct choice of drying method will improve the quality of food products, additives, and even herbs and medicines and will save costs [19]. 


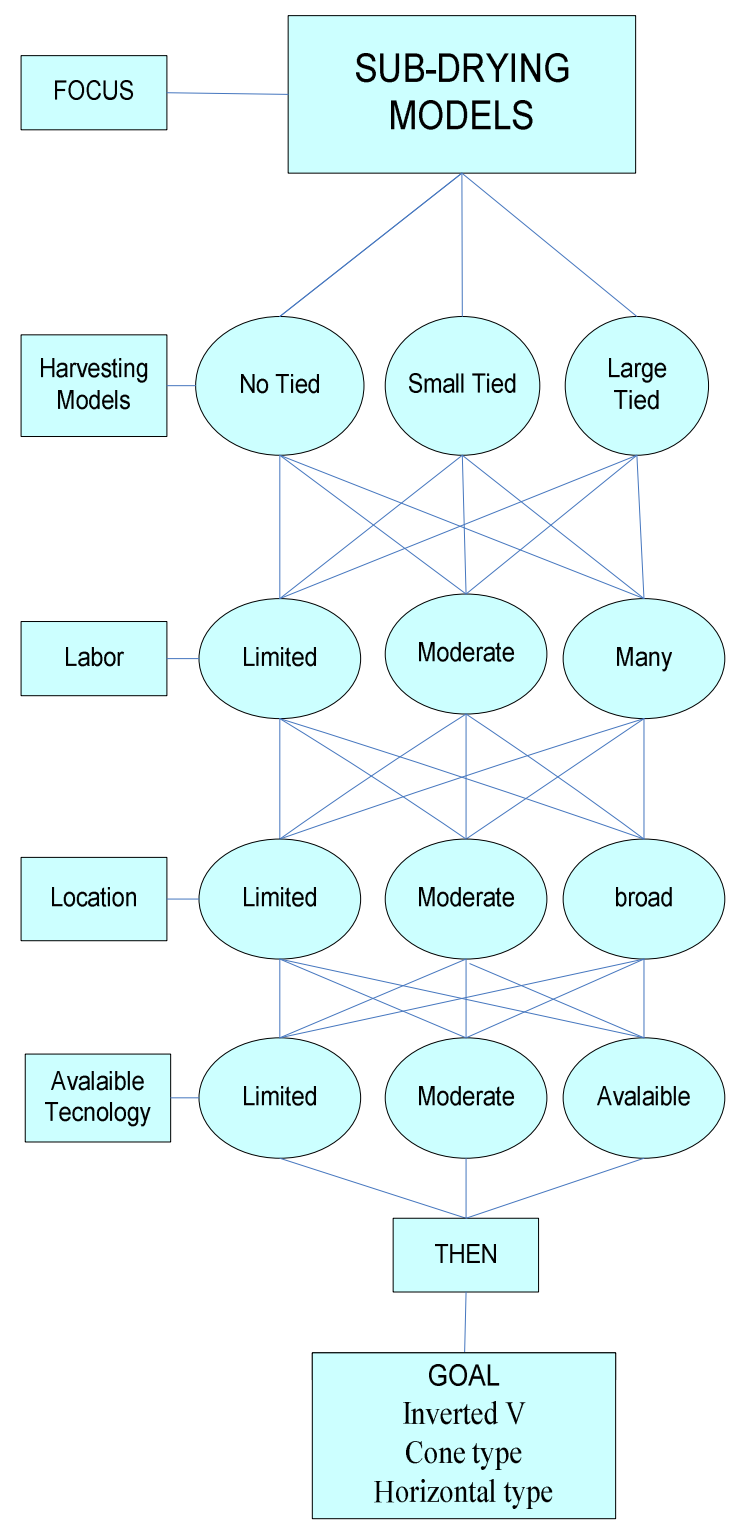

Fig. 9 Structure rule base sub- drying models

The next step in the harvest and post-harvest crop is sesame seed separation. Separation can positively impact seed crop results, no matter what size, the variations in density or which contaminants need to be removed. of standard operating procedure for separation, sub-models is considering harvesting submodels, workforce, location and availability of equipment/technology. Related to this subseparation model, more seeds are presented in Fig. 10.

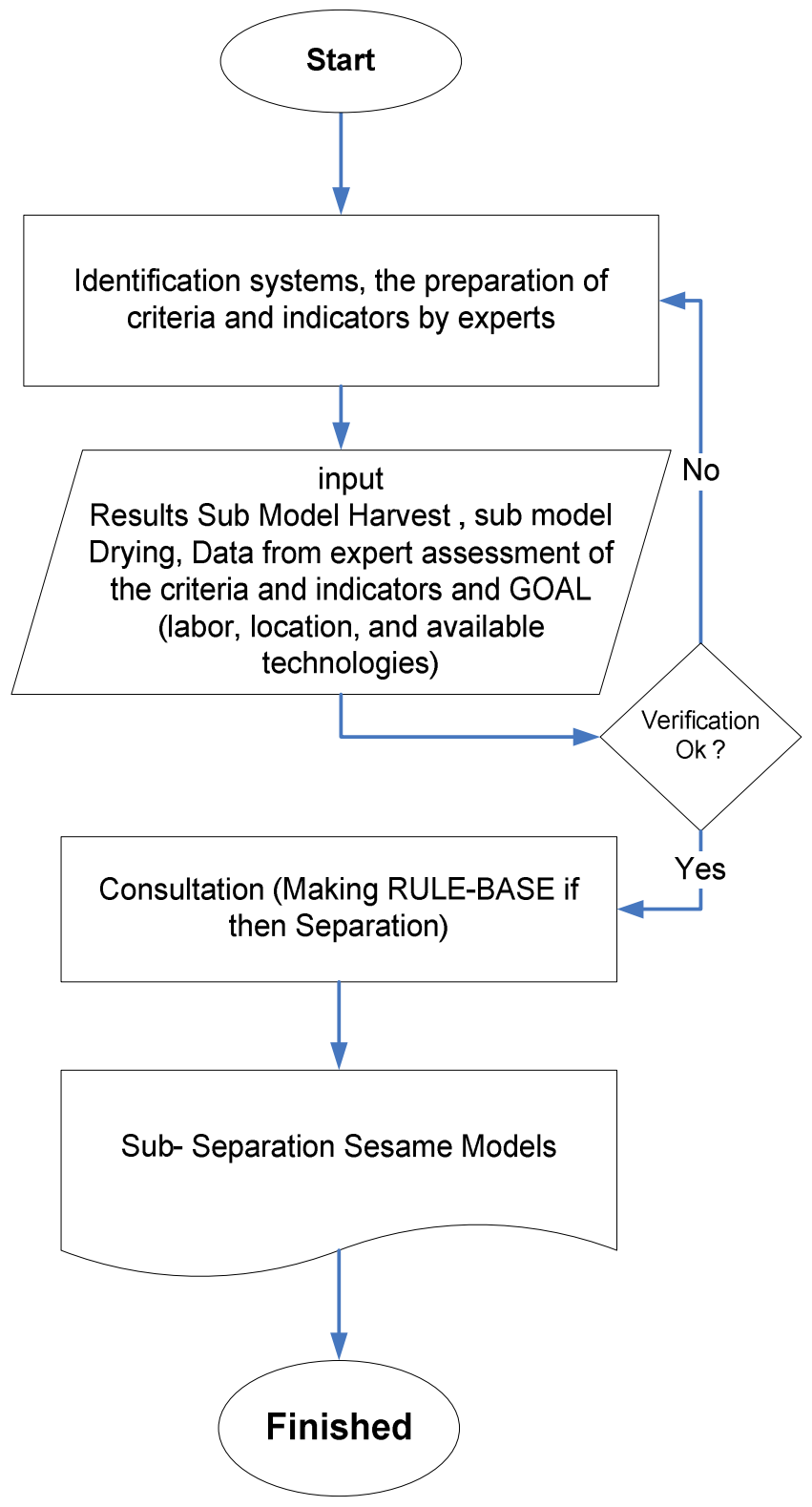

Fig. 10 Chart sub-model of separation of seeds

Sub-model of the separation of seed in Fig. 10, is an integral part of the previous sub-model. Therefore, it would be sub-models of effective and efficient separation.

The structure of the rule base sub-model separation sesame seeds, model based on criteria and indicators is presented in Fig. 11. 


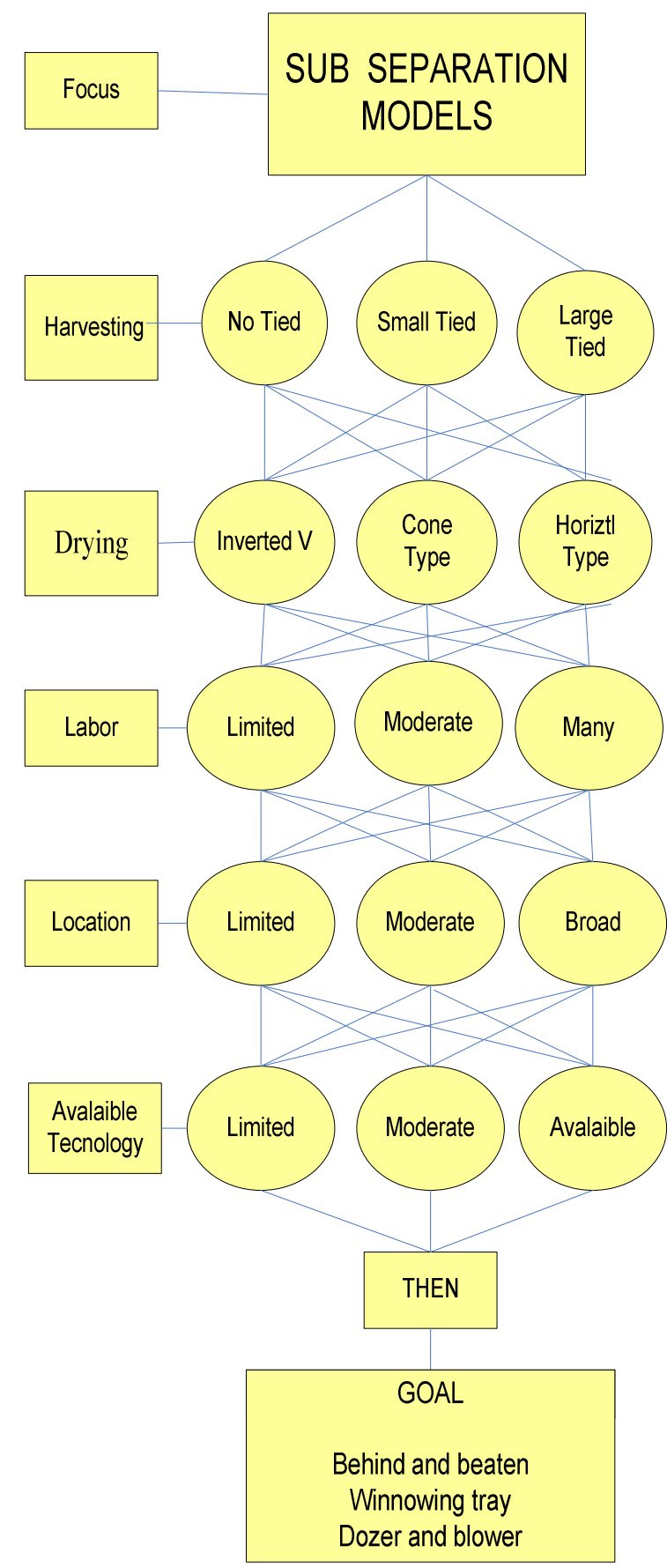

Fig. 11 Construction of sub-model of the separation of sesame seeds
The separation technique in Fig. 11, depends on how to do the harvest, labor, land area and the availability of technology that will determine a suitable method. Besides, it also determined the characteristics of the ease of pods or capsules to rupture or open sesame [20]-[21]. Of submodels, it can be in use appropriately in decision-making, where each submodel of software is prepared separately in a simple yet comprehensive manner. Decision-making can be used to determine how to repair planting, varieties and harvesting equipment technique more effectively and efficiently. [22]. Rule-base can be arranged in each submodel as in Table 3.

\section{CONCLUSIONS}

The decision-making process can be obtained from the analysis of a series of mutually influence and can be a complex or holistic approach. Thus, the standard operating procedure is a comprehensive decision. The components of the model which consist of the plant, labor, location, willingness instrument will determine the decision of how to harvest, drying and separation of seeds namely:

Sub Model for Harvesting have three (3) alternative options namely no Bundles/tied, small bundles/ tied and large bundles/tied. Is also consider five (5) factors / criteria: varieties, planting models, labor, location, and availability of technology.

- Sub Model for Drying with three (3) alternatives namely inverted $\mathrm{V}$, cones and horizontal models, to consider four (4) factors / criteria: harvest models, labor, location, and availability of technology and there are $>200$ an opportunity decisions.

- Sub model for Separation with three (3) alternatives namely Behind and beaten, Winnowing tray and Dozer and blower, consider four (4) factors / criteria: drying models, labor, location and availability of technology and there are 729 an opportunity decisions.

\section{ACKNOWLEDGMENT}

Thank you very much for supporting this research to (1) The Director General of Research and Community Service Director General of the Higher Education Ministry for Research Technology and Higher Education of the Republic of Indonesia. (2) The coordinator of Kopertis Region VII Surabaya, (3) The Rector of Merdeka Madiun University (4) The Chairman of the Institute for Research and Community Services Merdeka Madiun University. 
TABLE III

THE IMPORTANT COMPONENT OF HARVEST MODELS

\begin{tabular}{|c|c|c|c|c|c|c|c|}
\hline $\begin{array}{c}\text { Rule-Base } \\
\text { (if) }\end{array}$ & Varieties & Planting Models & Labor & Area drying & Tecnology & then & Goal \\
\hline 1 & No branch & Single Row & Limited & limited & limited & then & PN1 \\
\hline 2 & No branch & Single Row & Limited & limited & Moderate & then & PN1 \\
\hline 3 & No branch & Single Row & Limited & limited & Modern & then & PN1 \\
\hline 4 & No branch & Single Row & Limited & Moderate & limited & then & PN1 \\
\hline 5 & No branch & Single Row & Limited & Moderate & Moderate & then & PN1 \\
\hline 6 & No branch & Single Row & Limited & Moderate & Modern & then & PN1 \\
\hline 7 & No branch & Single Row & Limited & Wide & limited & then & PN1 \\
\hline 8 & No branch & Single Row & Limited & Wide & Moderate & then & PN1 \\
\hline 9 & No branch & Single Row & Limited & Wide & Modern & then & PNI \\
\hline etc.. & etc.. & etc.. & etc.. & etc.. & etc.. & etc.. & etc.. \\
\hline etc.. & etc.. & etc.. & etc.. & etc.. & etc.. & etc.. & etc.. \\
\hline etc.. & etc.. & etc.. & etc.. & etc.. & etc.. & etc.. & etc.. \\
\hline 213 & Branch & Squere & Many people & Moderate & Modern & then & PN2 \\
\hline 214 & Branch & Squere & Many people & Wide & limited & then & PN2 \\
\hline 215 & Branch & Squere & Many people & Wide & Moderate & then & PN2 \\
\hline 216 & Branch & Square & Many people & Wide & Modern & then & PN2 \\
\hline
\end{tabular}

Information: PN1 : Harvest Models 1

PN2 : Harvest Models 2

\begin{tabular}{|c|c|c|}
\hline \multicolumn{3}{|c|}{ Show at Table 3, the meaning of numbers : } \\
\hline 1 & $\begin{array}{l}\text { if varieties is no } \\
\text { branched, the } \\
\text { planting models is } \\
\text { a Single row, } \\
\text { available labor is } \\
\text { limited, area } \\
\text { drying is limited, } \\
\text { and available } \\
\text { technology is } \\
\text { limited }\end{array}$ & $\begin{array}{l}\text { Then: } \\
\text { The goal : harvest model is No } \\
\text { bundles/Tied } \\
\text { Harvest without bundles/ Tied : } \\
\text { It's how to harvest without No } \\
\text { bundles/Tied and be placed on the } \\
\text { spread because the available } \\
\text { location and available technology } \\
\text { make it easy for the next stage }\end{array}$ \\
\hline 216 & $\begin{array}{l}\text { if varieties is } \\
\text { branched, the } \\
\text { planting models is } \\
\text { square, the } \\
\text { available labor is } \\
\text { many people, area } \\
\text { drying is wide, and } \\
\text { available } \\
\text { technology } \\
\text { modern }\end{array}$ & $\begin{array}{l}\text { Then: } \\
\text { The goal : harvest model is small } \\
\text { bundles/Tied } \\
\text { Harvest small bundles/ Tied is a } \\
\text { way to harvest small bunch by } \\
\text { drying with inverted or cone with } \\
\text { a separation behind and pounded }\end{array}$ \\
\hline & If, ... & Then: \\
\hline & & \\
\hline
\end{tabular}

\section{REFERENCES}

[1] Budi,L.S“Application of plant cultivation techniques Sesame (Sesamum indicum L.) in increased production,"AGRITEKVol 7, Marc, 2007.

[2] Ayana.G.N. "Status of Production and Marketing of Ethiopian Sesame Seeds (Sesamumindicum L.)": A Review. Agricultural and Biological Sciences Journal Vol. 1, No. 5 pp. 217-223, 2015,

[3] Budi.LS.'The nature Appearance Agronomist Sesame Germplasm (Sesamum indicum L),"AGRITEKVol 5, Marc,2005.

[4] Budi.L.S, "Strategy and Structuring Development System Sesame Agroindustrial in Indonesia." International Journal On Advanced Science Engineering Information Technology. Vol 4. 2014

[5] Budi, LS "Correlation Study To The Land Component Content and Quality Some Genotype Sesame oil (Sesamum indicum L)". Agritek, Vol 12, pp. 26-35, 1 March 2011
[6] Budi. L.S."The Effect of Planing Method and Variety on Productivity of Sesame (Sesamum indicum L),"Bulletin Agronomy Vol 8, Aug. 2007.

[7] B. Uzun, E. Yol, S. Furat, M. Topakç, M. Çanakç, D. Karayel. "The Effects Of Diff Erent Tillage Methods On The Post-Wheat Second Crop Sesame: Seed Yield", Energy Budget, And Economic Return,"Turk J Agric,pp 399-407. 2012

[8] I.E. Ibrahim, A.E, Ahmed."Identification Of Factors That Influence Technical Efficiency Of Cash Crops Production (Sesame And Groundnut) In North Kordofan State, Sudan”. International Journal Of Scientific \& Technology Research2277-8616 Vol. 3, Oct. 2014

[9] D.R. Langham, J. Riney, G. Smith,T. Wiemers. "Sesame Harvest Guide."Oklahoma: Sesaco,2008

[10] L.R.RandVerma."Post-Harvest Management of Pulses". Indian Institute of Pulses Research Kanpur Rep.208-024, Oct. 2007

[11] Post-Harvest Handling Training Manual for Extension Workers No. 650-A-00-09-00003-00, USAID, 2012.

[12] C.F. Lisboa1, D.D.A. Silva1, I.R. Teixeira1, A.J.Campos, I.A. Devilla, and A.G. Silva. "Physiological quality of sesame seed harvested at different plant positions and maturity stages" . African Journal of Agricultural Research. Vol. 11(30), pp. 2825-2832, DOI: 10.5897/AJAR2016.11102 Article Number: C931B4859778, 28 July, 2016

[13] Sutojo, T, Mulyanto, E \& Suhartono, V, Artificial intelligence, Andi Offset, Yogyakarta. .2011

[14] Kusumadewi, Sri, Artificial Intelligence (Teknik dan Aplikasinya), Graha Ilmu,Yogyakarta. 2003

[15] Marimin,"Theory and Application of Expert System in Managerial Technology”. Bogor: IPB Press. 2005.

[16] Oliver "Separation Technology for the Seed Industry". USA. 2012.

[17] Varsha.S, Gupta. S, Pattnaik.S,"AartiGoyal"A Novel Approach to GSA, GA and Wavelet Transform to Design Fuzzy Logic Controller for $1 \phi$ Multilevel Inverter", International Journal of Power Electronics and Drive System (IJPEDS) Vol. 7, No. 4, pp. 1200 1211, December 2016,

[18] A. Nadeem, S.D. Kashani, N. Ahmed, M. Buriro, Z. Saeed, F. Mohammad, S. Ahmed, "Growth and Yield of Sesame (Sesamum indicum. L.) under the Influence of Planting Geometry and Irrigation Regimes," American Journal of Plant Sciences, pp.980-986, April, 2015

[19] Djaeni.M, "Innovation And Dryer System Downstream Dehumidification Through Air With Zeolite For Improving The Quality Of Food Ingredients, UNDIP Press, 2016 
[20] Bachubhai A. Monpara.and Devshibhai R. Vaghasia,"Optimizing Sowing Time and Row Spacing for Summer Sesame Growing inSemi-arid Environments of India.”,Int.J.Curr.Res.Aca.Rev. 4(1):122-131. 2016

[21] St. Stamatov, M. Deshev. St. Ishpekov And R. Zaykov," Application Of The Subjective Independent Method For Evaluation Of Hybrid Materials Sesame (Sesamum Indicum L) In The Direction Of Mechanized Harvesting" Bulgarian Journal of Agricultural Science, 22 982-986, (No 6) 2016.
[22] Putri, R.E. Yahya, A. Adam, N.M. and Aziz, S.A, Performance Evaluation of Yield Monitoring System for Rice Combine Harvester in Selangor, Malaysia, IJASEIT, Vol.6 (2016) No. 1 ISSN: 20885334

[23] A. Z. Rakhman, et al., " Fuzzy Inference System with Tsukamoto Method as a Gathering of Selection of Concentration Selection (Case Study: Department of Informatics UII), "in National Seminar on Information Technology Applications 2012 (SNATI 2012), Yogyakarta, 2012. 